\title{
Characterization and Remediation of Karst Collapse Columns for Mining Safety and Environmental Protection: A Case Study in Renlou Coal Mine, China
}

\author{
Shuning Dong ${ }^{1}$, Hao Wang ${ }^{1} \&$ Wanfang Zhou $^{2}$ \\ ${ }^{1}$ Xi' an Research Institute of China Coal Technology \& Engineering Group Corp. Xi'an, Shaanxi 710054, China \\ ${ }^{2}$ ZeoEnvironmental, LLC., Knoxville, Tennessee, USA \\ Correspondence: Wanfang Zhou, ZeoEnvironmental, LLC., Knoxville, Tennessee, USA. E-mail: \\ zhou_wanfang@yahoo.com
}

Received: April 3, 2018

Accepted: April 20, 2018

Online Published: May 25, 2018

doi:10.5539/enrr.v8n2p128

URL: https://doi.org/10.5539/enrr.v8n2p128

\begin{abstract}
Karst collapse columns are unique collapse structures in karst terranes. Coal mining in China has exposed numerous such features of tens of meters in diameter and hundreds of meters in height. Hydraulically conductive collapses functioned as groundwater pathways between underground workings and aquifers, resulting in water inrushes during coal mining. Over the last 60 years, water inrushes through these collapses have caused fatalities, economic losses, and degradation in the environment. Determination of locations and hydrogeological characteristics of the karst collapse columns are essential in preventing water inrush incidents through them. Advanced geophysical prospecting, directional drilling, aquifer testing and accompanied dye tracing are effective approaches to detecting and characterizing these structures. Five geophysical techniques consisting of both surface and underground geophysical surveys and directional drilling of three exploratory boreholes up to $986 \mathrm{~m}$ deep identified a concealed collapse feature of more than $135 \mathrm{~m}$ high in Renlou Coal Mine, China. The roof of the collapse feature was at approximately $785 \mathrm{~m}$ deep, and there was an open void of $1.5-2 \mathrm{~m}$ high at the top. Geotechnical properties, results from packer testing and tracer testing, monitoring of potentiometric pressures, and geochemical fingerprinting suggested that this collapse column was hydraulically conductive and still actively developing. Water in the confined thin-bedded limestone and Ordovician limestone aquifer that either overlies or underlie coal seams could flow into the underground working areas if this feature were not identified in advance but encountered during mining. A grouting program was designed and implemented to construct a water plug in the collapse that effectively cut off the hydraulic connections from the aquifers to the underground workings. Successful construction of the water plug in the collapse was confirmed by performance monitoring of the aquifers.
\end{abstract}

Keywords: karst collapse columns, water inrushes, coal mines, 3D seismic, directional drilling, grouting

\section{Introduction}

More than $90 \%$ of China's coal output is produced in north China, and approximately 300 billion tons of proven reserves are threatened with the underlying Ordovician karst aquifers. In the past 60 years, more than 1,300 groundwater inrush accidents occurred in coal mines in China and many of these water inrushes were through a unique type of karst features known as paleo-collapse structures or paleo-collapse breccia pipes or karst collapse columns (used in this paper and abbreviated as KCC) (Li et al., 2017; Wu et al., 2013). These KCCs functioned as hydrogeologically conductive pathways for the groundwater flow from the Ordovician karst aquifer to working faces under mining influences (Zhou, 1997; Benson et al., 1991). Unlike cover collapses or sinkholes that are often caused by human activities (Newton, 1987; Beck, 1991; Beck \& Wilson, 1987; Zou, 1994), KCCs are rock collapses that occurred in the geological past (White, 1988; Sangster, 1988; Li \& Zhou, 1989; Vegter \& Foster, 1992). Depending on the internal cementation of the KCCs, they can be active or inactive in the groundwater circulation system. Inactive KCCs can be reactivated by human activities such as dam construction, mining underground minerals, pumping groundwater, and development of landfills. They may also be reactivated by natural events such as earthquakes and neo-tectonic activities. 
Usually the infill materials in the karst collapse structures are tabular 5-40 cm angular fragments which display random orientation. Sides are subparallel and contacts between host and fills are sharp and irregular. In most cases, the matrix consists of clastic sediments without cement or mineralization. These structures are generally perpendicular to the ground surface. However, they could become inclined as a result of tectonic movements but remain perpendicular to the surrounding strata. Voids may be present at the top of the structures and drill bits can drop noticeably during borehole drilling. Closed depressions sometimes form in the surficial sediments.

The effects of KCCs can be observed in the various karst features of the carbonate aquifers and the yields of oil and gas reservoirs. They can also be seen in the interrelationships between important mineral deposits and karst aquifers which pose safety and environmental problems in mining engineering.

\section{Karst Collapse Columns Encountered during Mining in North China}

Geology and climate are two major factors affecting the development of karst features. Usually, there have been several phases of karstification during geological history. In China, for example, the most striking karstification is found in (1) the Caledonian Orogeny unconformity between the Ordovician limestone and middle carboniferous series in northern China; (2) the unconformity between the Lower Permian limestone and the Upper Permian Series in southern China; (3) the pre-Jurassic karstification in the Sichuan basin; and (4) the pre-Tertiary buried karst in northern China.

KCCs are widely distributed in north China as a result of these episodic karstification in the geological past. They have been found in over 50 coalfields and their total number exceeds 3,000 with an intensity of up to 70 collapses $/ \mathrm{km}^{2}$ (Zhou, 1997). Table 1 summarizes some of KCCS reported in north China's coalfields. In some mining panels, such collapse structures comprise $30 \%$ of the total mined areas. Figure 1 shows some common profiles of KCCs reported in north China. While the majority of the KCCs are buried underground, some are exposed to surface and expressed as depressions. The main characteristics of the KCCs include the following:

- They are recognizable in plan view as patches of breccia with miscellaneous lithological composition, generally derived from overlying strata and completely enclosed in lower bedrock.

- Diameters range from tens to hundreds of meters with the largest measuring 1,050 m (Dong, 2016).

- In profiles, they take the form of vertical cylinders several hundred meters deep.

- No bedding is apparent inside these structures and the different rocks are intermixed and poorly sorted. They generally contain higher proportions of displaced blocks and the adjoining strata are offset as a result of dissolution-collapse. Fragments tend to be sharply angular, typically rotated, show little sign of wear and appear to have dropped from their original stratigraphic position.

The KCCs encountered in north China are of different hydrogeological types depending primarily upon the lithology of their internal rock blocks, extents of weathering and cementation, and the secondary structures associated with the collapses (Zhou \& Beck, 2012). Based on the exposed karst collapses from drillings and excavations, the KCCs can be permeable, impermeable and poorly permeable. In different karst collapses or different locations of the same collapse, the rock blocks may have different hydrogeological properties. In Yangquan Coal Mine of Shanxi province, none of the intercepted 960 KCCs was permeable to groundwater, whereas all of the six collapses encountered in Tangjiazhuang Coal Mine were hydraulically conductive. On average, $62 \%$ of the encountered KCCs are permeable or poorly permeable (Li \& Zhou, 2015). Figure 2 shows profiles of the three types of KCCs. All of the three collapses were exposed in Fangezhuang Coal Mine of north China. KCC No. 9 is permeable; No. 2 is impermeable; and No. 1 poorly permeable. The permeable KCCs consist of weathered rock blocks, but they are typically unconsolidated and not cemented. The impermeable KCCs consist of weathered rock blocks that are often cemented by weathered shale and mudstone. The poorly permeable KCCs consist of partially cemented rock blocks with secondary fractures around the border of the collapses. 
Table 1. Select KCCs that were reported in north China's coalfields

\begin{tabular}{|c|c|c|c|c|c|c|}
\hline \multirow{2}{*}{ Province } & \multirow{2}{*}{ Location } & \multirow{2}{*}{ Number of KCCs } & \multicolumn{3}{|c|}{ Max. size of collapses (m) } & \multirow{2}{*}{ Water inrush } \\
\hline & & & length & width & height & \\
\hline \multirow{5}{*}{ Shaanxi } & Xishan Coal Mine, Taiyuan & 1300 & 40 & & & \\
\hline & Yangquan Coal Mine & 960 & 300 & & 600 & \\
\hline & Huoxian Coal Mine & 405 & 60 & & & 2 \\
\hline & Zhuangjiazhuang Coal Mine, Fenxi & 360 & 30 & & & 1 \\
\hline & Shenlin Coal Mine & 75 & 30 & & & \\
\hline \multirow{6}{*}{ Hebei } & Jingxing Coal Mine & 120 & 300 & 23 & 300 & 1 \\
\hline & Fenfeng Coal Mine No. 1 & 6 & 200 & 40 & & \\
\hline & Fengfeng Coal Mine no. 4 & 20 & 73 & 150 & & \\
\hline & Yangquhe Coal Mine & 6 & 204 & 57 & & \\
\hline & Fangezhuang Coal Mine, Kailuan & 9 & 95 & 74 & 280 & 4 \\
\hline & Tangjiazhuang Coal Mine, Kailuan & 6 & 116 & & 50 & \\
\hline \multirow{3}{*}{ Henan } & Hebi Coal Mine & 22 & 200 & 60 & 398 & \\
\hline & Tongyie Coal Mine, Anyang & 22 & & & & 1 \\
\hline & Lifeng Coal Mine, Jiaozuo & 1 & & & & 1 \\
\hline \multirow{12}{*}{ Jiangsu } & Dahuangsha Shaft, Xuzhou & 17 & 200 & 146 & & 1 \\
\hline & Qingshanzong Shaft No. 1 & 1 & & & & 1 \\
\hline & Qingzhuan Coal Mine & 1 & 38 & 19 & & \\
\hline & Liuxing Coal Mine & 1 & & 20 & & \\
\hline & Jincheng Coal Mine & 27 & 125 & 62 & & \\
\hline & Xinhe Coal Mine & 3 & 136 & 100 & & \\
\hline & Jiahe Coal Mine & 1 & 135 & 100 & & 1 \\
\hline & Wangzhuang Coal Mine & 1 & 122 & 93 & & \\
\hline & Quanzhao Coal Mine & 7 & 60 & 40 & & \\
\hline & Hanqiao Coal Mine & 4 & 170 & 100 & & \\
\hline & Dongzhuang Coal Mine & 1 & 280 & 200 & & \\
\hline & Yian Coal Mine & 1 & & & & \\
\hline
\end{tabular}

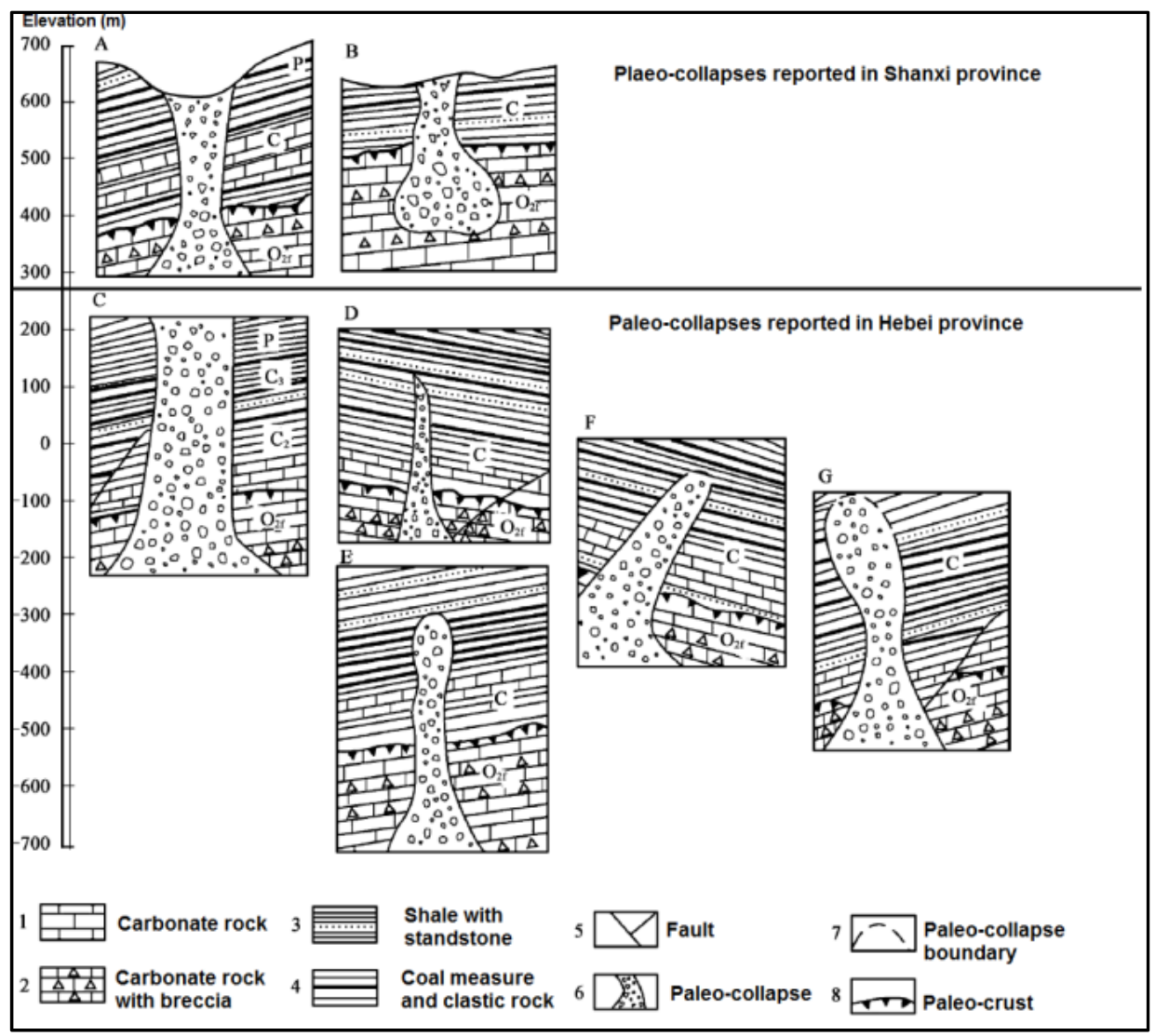

Figure 1. Select KCC profiles reported in north China (modified from Lu and Zhang, 2008). Elevation in meters is shown on the left side of the figure 


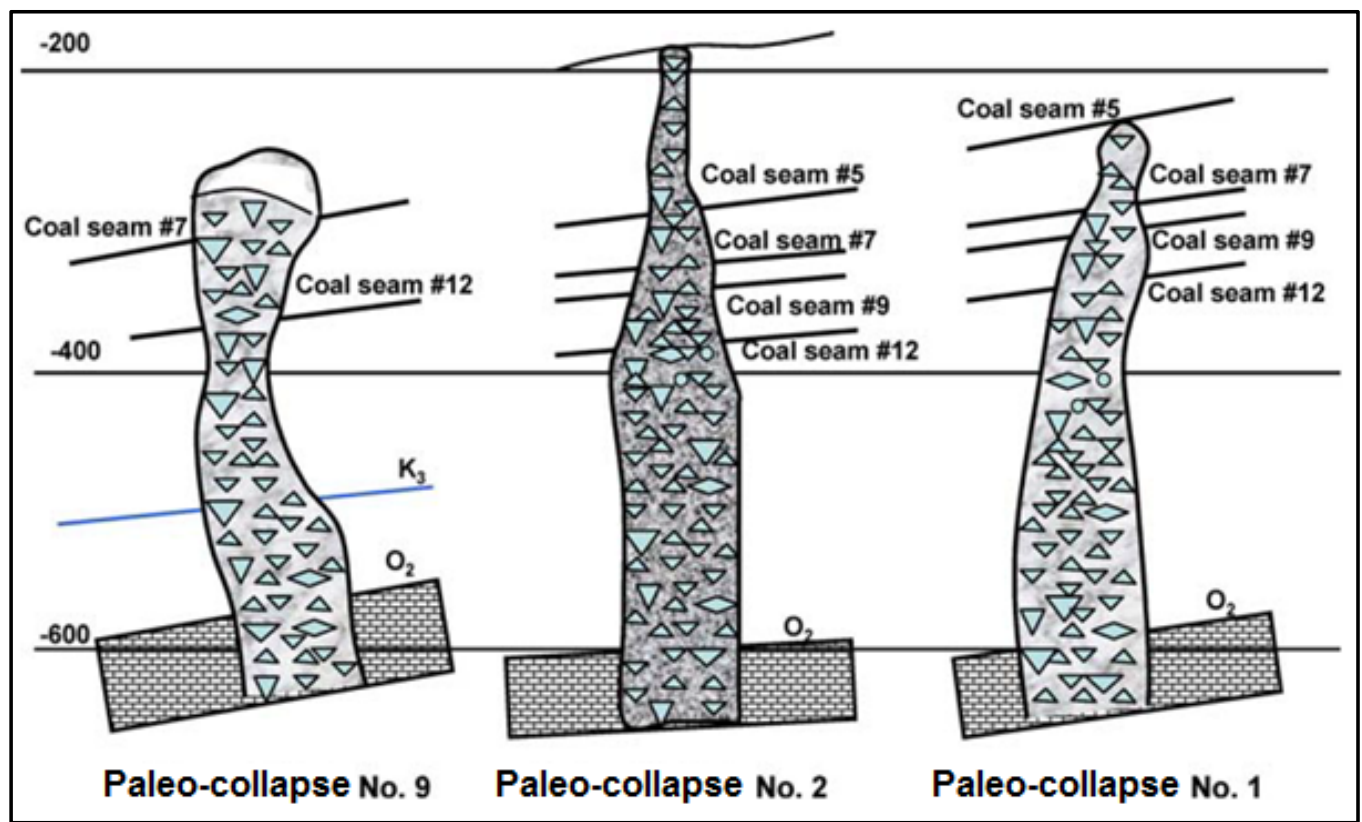

Figure 2. Longitudinal cross sections of KCCs No. 9 (permeable), No. 2 (impermeable) and No. 1 (poorly permeable) in Fangezhuang Coal Mine (modified from Yin and Zhang, 2005). Elevation in meters is shown on the left side of the figure

\section{Formation Mechanisms of Karst Collapse Columns}

Formation of KCCs may involve polygenetic processes. However, the bottom of these collapse structures is usually in the underlying karstified Ordovician limestone, and the lithological character of the breccia gives a strong impression of collapse of upper strata. Gypsum in the Ordovician limestone is recognized as playing an important role in KCC formation (Li \& Zhou, 1990). Sulfate-reducing bacteria (SRBs) may help initiate and accelerate the dissolution process of the carbonate rocks (Lu \& Zhang, 2008). Figure 3 presents a schematic diagram depicting the compound dissolution process in which the limestone is dissolved by both carbonic acid and sulfuric acid. In additional to presence of natural acid-producing gases, gypsum can produce $\mathrm{H}_{2} \mathrm{~S}$ by SRBs and additional $\mathrm{CO}_{2}$ by interacting with carbonate rocks.

In Shanxi province, gypsum is present in the Middle Ordovician Fengfeng Formation. It contains up to $60 \%$ of secondary gypsum, present as thick massive beds, nodular gypsum and gypsum interbedded with mudstone and dolomite. The formation rests on the Majiagou Formation which also contains some gypsum and is the major regional aquifer. In the Tiejingou deposit near Yangquan the Fengfeng Formation ranges in thickness from several tens to more than one hundred meters. Within the formation large palaeokarst caves, situated in the present vadose zone, have collapsed and are filled with breccia. However, karst fissures are still undergoing dissolution and enlargement. The active dissolution of gypsum, indicated by sulphate-rich springs, confirms that the gypsum karst is still evolving.

Shanxi province is in a semi-arid environment undergoing uplift. Palaeokarst, such as that originally developed under phreatic conditions in the Ordovician Fengfeng Formation, has been uplifted above the water table and preserved. In the Fengfeng Formation the dissolution of the gypsum has caused the formation of extensive breccia beds with associated breccia pipes or collapse columns that have propagated upwards through the active coalfields (Li \& Zhou, 2006). Preservation of gypsum karst is likely when climatic conditions change causing a reduction in the availability of water to the natural systems. In this way the gypsum karst of southwest Oklahoma (Johnson, 1990) was preserved. Pollen/spore samples from underground deposits have yielded a temperate, but dry forest/grassland assemblage when the collapses occurred (Lu \& Copper, 1997). 


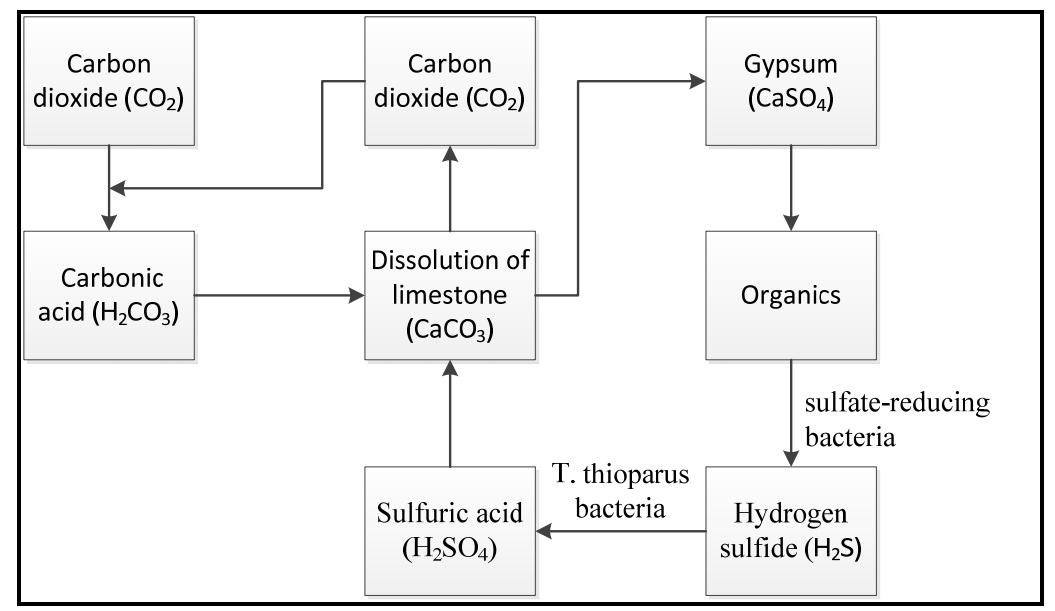

Figure 3. Schematic diagram of compound dissolution of limestone and gypsum

In active karstification situations gypsum can dissolve very rapidly and caves can quickly enlarge, or amalgamate, become unstable and collapse. When this occurs collapse columns or breccia pipes can propagate upwards and cause surface collapse. The sizes of the breccia pipes and collapses relates directly to the thickness and strength of the gypsum deposits. The more massive, thick and homogeneous the deposit, the larger are the caves that can be supported and consequently the larger the collapses and breccia pipes. When the gypsum between the collapse columns also dissolves an irregular bed of breccia may form.

The nature of the underlying and overlying strata adjacent to the gypsum also has a profound influence on the way gypsum karst develops. In sequences where the adjacent rocks are largely impervious the karst can only develop along the joints in the gypsum. In phreatic situations, where the gypsum is underlain, or overlain, by porous dolomites or sandstones, water enters the gypsum in a diffuse way. When this happens, dissolution progresses on many fronts and maze cave systems can develop, such as those observed in the Ukraine (Andrajchouk \& Klimchouk, 1993). In this situation much of the dissolution occurs at the contacts with the adjacent strata which may also be karstified. In the maze caves the passages range from joint-controlled networks of small stable caves with little dissolution, to networks of actively dissolving conduits with large and unstable cavities; these commonly have subsidence associated with them.

Where gypsum is in contact with adjacent carbonate rocks, the water chemistry associated with the dissolution phenomenon is different to that for gypsum alone, or for limestone alone. The presence of gypsum together with carbonate rocks will usually cause a compound karstification effect. Waters rich in calcium carbonate can aggressively dissolve gypsum and simultaneously deposit calcite (Wigley, 1973). When this occurs the breccias caused by the dissolution of the gypsum may be cemented. Carbonate-cemented breccias, possibly formed by this mechanism, occur in the Fengfeng Formation. Gypsum dissolves easily in flowing water and increases the amount of sulphate in the water. When anhydrite hydrates to gypsum, the expansion can cause brecciation of the mineral, brecciation of the adjacent rock, and injection of fibrous gypsum veins; such deposits are present in the Ordovician Fengfeng Formation.

The solubility of gypsum in calcium carbonate-rich waters may be decreased by the common ion effect. Conversely, the presence of sodium, magnesium and chloride ions (possibly derived from interbedded dolomites and halite beds) can enhance the dissolution of gypsum. Experimental work shows that the presence of sulphate in the water increases the dissolution rate for dolomite. For water with an $\mathrm{SO}_{4}{ }^{2-}$ content of $1 \mathrm{mg} / \mathrm{l}$ the dissolution amount for dolomite was $1.67 \mathrm{mg} / \mathrm{l}$ while that for limestone was only $0.94 \mathrm{mg} / \mathrm{l}$ (Lu \& Cooper, 1997). The result of this groundwater chemistry on karstification is that very intense and pervasive leaching of the carbonate deposits, especially dolomites, can occur resulting in a honeycomb structure of very little strength. The dissolution of the gypsum, when it is complete, can leave just an insoluble residue, commonly of silt or clay.

After the gypsum dissolved and was removed by groundwater, numerous cavities or fractures were left behind. Solution of the gypsum layers and continuous dissolution of the limestone eventually led to the collapse of the overlying strata. Development of a KCC is envisaged as a more or less continuous process which progresses upward from an initial conduit (cave) until an equilibrium pressure arch configuration is attained. This occurs when a collapse reaches a lithologic unit of sufficient strength, or the cavity is completely filled with breccia and thus becomes self-supporting. 


\section{Impacts of Karst Collapse Columns on Mining and the Environment}

The absence of coal seams and the sudden inrush of karst water from the Ordovician limestone have been encountered in the mines of the Permo-Carboniferous coalfields of north China. The KCCs functioned as groundwater pathways for some of these events. Figure 4 shows three scenarios in which the pressurized karst water in the Ordovician limestone flows into the mining areas through KCCs. The relative location of a mine to the active flow zone or karst conduits in karst aquifers determines the amount of water that can flow into the mine. In the presence of a large water-pressure difference, hydrofracturing will facilitate upward flow of the Ordovician karst water into mines. Mining drifts do not have to intercept the KCCs directly to cause a geohazards but may instead intercept faults or fractures connected to them. However, once a water inrush occurs and significant water flows into the workings, the whole mine may become flooded. In cases where different aquifers, several hundred meters apart, become hydraulically connected, the impacts on safety, economy and the environment can be alarming.

Table 2 lists 14 water inrushes through KCCs in coal mines, including the largest inrush in the world, which occurred in Fangezhuang Mine in 1984. Karst water gushed into the mine at a flow rate of $34 \mathrm{~m}^{3} / \mathrm{s}$ at a depth of 313 $\mathrm{m}$ below sea level (bsl). The surface level is $27 \mathrm{~m}$ above sea level (asl). The whole mine was flooded within $21 \mathrm{~h}$ and as a result, the regional water table in the Ordovician limestone dropped from $5.94 \mathrm{~m}$ asl to $111.09 \mathrm{~m}$ bsl. The cone of depression covered approximately $84 \mathrm{~km}^{2}$ with a north-south axis of $25 \mathrm{~km}$ long. The fall in the water table in the Ordovician limestone caused serious problems for local residents, including drying up of their water supply wells, contamination of the groundwater and formation of cover-collapse sinkholes. The water inrush led to the development of 17 cover-collapse sinkholes with diameters from 2.5 to $3 \mathrm{~m}$ and depths of 3 to $12 \mathrm{~m}$.

Table 2. Case histories of water inrushes through KCCs in north China

\begin{tabular}{|c|c|c|c|c|}
\hline Mine & Date & $\begin{array}{l}\text { Flow } \\
\text { rate } \\
\left(\mathbf{m}^{3} / \mathbf{s}\right)\end{array}$ & Description & Damage \\
\hline $\begin{array}{l}\text { Taoyuan Coal } \\
\text { Mine }\end{array}$ & 2013 & 2.8 & $\begin{array}{l}\text { Karst water from the Ordovician limestone flowed into the cut-hole of } \\
1035 \text { working panel through a concealed KCC. }\end{array}$ & $\begin{array}{l}\text { Mine was flood with } 1 \\
\text { person missing. }\end{array}$ \\
\hline $\begin{array}{l}\text { Shenjia-zhuang } \\
\text { Coal Mine }\end{array}$ & 2012 & 0.36 & $\begin{array}{l}\text { Karst water from the Ordovician limestone flowed into mine through a } \\
\text { concealed } \mathrm{KCC} \text { that has developed to } 50 \mathrm{~m} \text { below the coal seam. }\end{array}$ & Mine was flooded. \\
\hline $\begin{array}{l}\text { Huangsha Coal } \\
\text { Mine }\end{array}$ & 2011 & 3 & $\begin{array}{l}\text { Karst water from the Ordovician limestone flowed into working panel } \\
112106 \text { at depth of } 800 \mathrm{~m} \text { through a compound structure consisting of a } \\
\text { KCC and a fracture. }\end{array}$ & Mine was flooded. \\
\hline $\begin{array}{l}\text { Luotuoshan Coal } \\
\text { Mine }\end{array}$ & 2010 & 2 & $\begin{array}{l}\text { Karst water from the Ordovician limestone flowed into mine via } 870 \mathrm{~m} \\
\text { return airway of \#16 coal seam. }\end{array}$ & $\begin{array}{l}\text { Mine was flood with } 32 \\
\text { fatalities. }\end{array}$ \\
\hline $\begin{array}{l}\text { Dongpang Coal } \\
\text { Mine }\end{array}$ & 2003 & 19.5 & Karst water from a karst collapse structure flowed into the mining area. & Mine was flooded. \\
\hline Wucun Coal Mine & 1999 & 0.67 & Karst water from a karst collapse structure flowed into the mining area. & Panel was flooded. \\
\hline Renlou Coal Mine & 1996 & 19 & $\begin{array}{l}\text { Karst water flowed into } 7222 \text { working face at depth of } \sim 380 \mathrm{~m} \text { through a } \\
\text { KCC. The collapse connected thin-bedded limestone and Ordovician } \\
\text { limestone with the mining area. }\end{array}$ & $\begin{array}{l}\text { Mine was flooded, shut } \\
\text { down about } 6 \text { months. }\end{array}$ \\
\hline $\begin{array}{l}\text { Huaxian Coal } \\
\text { Mine }\end{array}$ & 1984 & 0.06 & $\begin{array}{l}\text { Karst water from a karst collapse structure flowed into surrounding } \\
\text { fractures and then into the horizontal drift in the Ordovician limestone. }\end{array}$ & Drift was abandoned. \\
\hline $\begin{array}{l}\text { Fagezhuang Coal } \\
\text { Mine, Kailuan }\end{array}$ & 1984 & 34 & $\begin{array}{l}\text { This is the biggest water inflow incident in the world. The mining coal } \\
\text { seam was } 180 \text { m above the Ordovician limestone, but they are connected } \\
\text { by a karst collapse structure. The reactivation of the collapse may be } \\
\text { associated with a recent earthquake in this area. Grouting boreholes } \\
\text { revealed that the top of the sinkhole was unfilled with sediments. }\end{array}$ & $\begin{array}{l}\text { Mine was flooded, resulted } \\
\text { in } 9 \text { fatalities, } 17 \text { cover } \\
\text { sinkholes, and the adjacent } \\
\text { three mines were threatened. }\end{array}$ \\
\hline $\begin{array}{l}\text { Fagezhuang Coal } \\
\text { Mine, Kailuan }\end{array}$ & 1983 & 0.23 & $\begin{array}{l}\text { A small fault with displacement of } 0.2-0.5 \mathrm{~m} \text { was intercepted by a working } \\
\text { stope. Karst water flowed through a karst collapse structure into the fault } \\
\text { and then to the working stope. }\end{array}$ & Working stope was flooded. \\
\hline $\begin{array}{l}\text { Fagezhuang Coal } \\
\text { Mine, Kailuan }\end{array}$ & 1978 & 1 & $\begin{array}{l}\text { Water flowed into the mine from the sandstone, which is } 160 \mathrm{~m} \text { above the } \\
\text { underlying Ordovician limestone. A sluice gate was constructed to isolate } \\
\text { the water inflow area and a } 0.2-\mathrm{m} \text { fracture was revealed, connected with a } \\
\text { karst collapse structure. }\end{array}$ & $\begin{array}{l}\text { Part of a drift and a working } \\
\text { stope }\left(70,188 \mathrm{~m}^{3}\right) \text { was } \\
\text { flooded }\end{array}$ \\
\hline $\begin{array}{l}\text { Lifeng Coal Mine, } \\
\text { Jiaozuo }\end{array}$ & 1967 & 2 & $\begin{array}{l}\text { Karst developed very well in the area. Intensive mine water drainage } \\
\text { reactivated the karst collapse structure. }\end{array}$ & $\begin{array}{l}\text { A working stope was flooded, } \\
\text { and } 1 \text { fatality occurred. }\end{array}$ \\
\hline $\begin{array}{l}\text { Huoxian Coal } \\
\text { Mine }\end{array}$ & 1967 & 0.13 & $\begin{array}{l}\text { Karst water flowed into an excavating drift through a karst collapse } \\
\text { structure and a connecting fault. }\end{array}$ & Drift was abandoned. \\
\hline $\begin{array}{l}\text { Tongyie Coal } \\
\text { Mine, Anyuang }\end{array}$ & 1965 & 0.39 & $\begin{array}{l}\text { A water inspection borehole drilled into a karst collapse structure from a } \\
\text { drift. The initial water flow rate was } 0.5 \mathrm{~m}^{3} \mathrm{~min}^{-1} \text { and water flow rate } \\
\text { increased to } 23.3 \mathrm{~m}^{3} \mathrm{~min}^{-1} \text {. An exploration borehole revealed } 17 \text { cavities } \\
\text { within } 50 \mathrm{~m} \text { of the collapse with the maximum bit-drop of } 2.59 \mathrm{~m} \text {. }\end{array}$ & Mine was flooded. \\
\hline
\end{tabular}




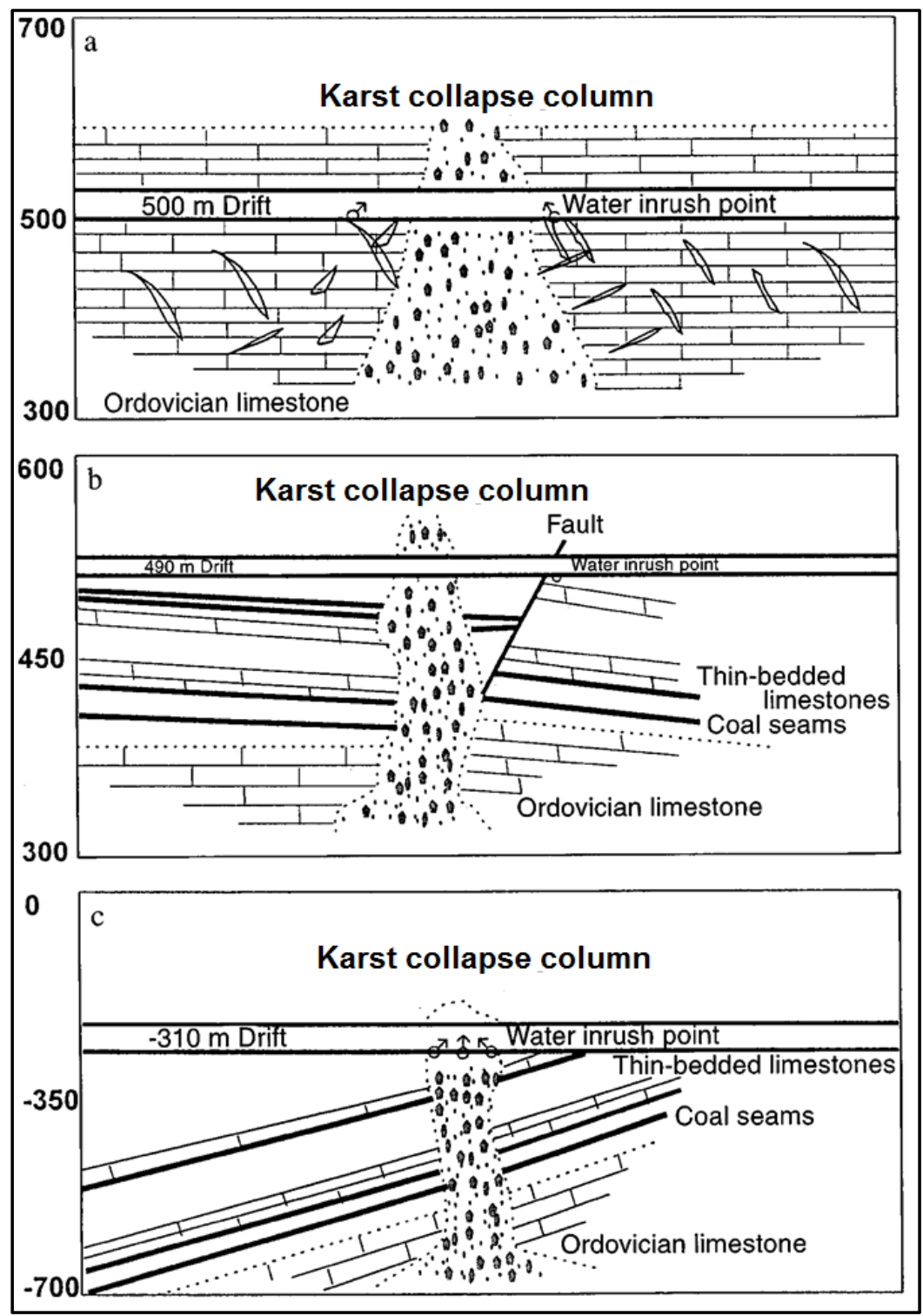

Figure $4 \mathrm{a}-\mathrm{c}$. Scenarios where karst water from Ordovician limestone flows into workings through KCCs. 4a through karst collapse-connected fissures; 4b through karst collapse-connected faults; 4c through karst collapse columns (modified from Zhou, 1997). Elevation in meters is shown on the left side of the figure

Table 2 also includes a water inrush that occurred at the mine of this case study, Renlou Coal Mine, Anhui province in 1996. The water inrush occurred in working panel 7222 of $380 \mathrm{~m}$ deep. Figure 5 shows the lithology in the mine and the water-inrush point. The panel was flooded within $10 \mathrm{~h}$. The final water level was stabilized at $15.59 \mathrm{~m}$ asl, which is approximately the same elevation of the water level in the Ordovician limestone. The maximum water inflow was $19 \mathrm{~m}^{3} / \mathrm{s}$. The water inrush resulted in a water level drop of $7.04 \mathrm{~m}$ in an Ordovician limestone monitoring well $16.2 \mathrm{~km}$ away. Investigations in response to the water inrush and subsequent grouting confirmed that the water pathway was a KCC. The column was nearly vertical and oval-shaped with long axis of $30 \mathrm{~m}$ and short axis of $25 \mathrm{~m}$. Although none of the boreholes reached the bottom of the $\mathrm{KCC}$, the collapse column was at least $300 \mathrm{~m}$ high, having its root in the Ordovician limestone and roof in the Quaternary and Tertiary formations. The top section of the KCC consisted of an open void, which suggests that the KCC was still actively developing upward. The mine was restored six months later after a successful grouting program.

A second relatively smaller water inrush occurred at working panel $7_{2} 18$ in the same coal mine in 1999 . Timely recognition of water inrush indicators including pressure increase in front of the tunnel, deformation of tunnel support structures, water flow increasing from 5 to $9 \mathrm{~m}^{3} / \mathrm{h}$ allowed quick responses so that the risk for a catastrophic water inrush was mitigated by systematic investigation and grouting. No serious damages occurred at 
the second encounter with production rate slightly affected. The investigation confirmed that this water inrush was also through a KCC that was oval-shaped with its long axis of $40 \mathrm{~m}$ and short axis of $30 \mathrm{~m}$. It has developed to a position approximately $20 \mathrm{~m}$ below \#8 coal seam. This collapse was also actively developing upward.

These water inrush incidents suggest that the hydrogeological conditions in Renlou Coal Mine meet the three basic requirements for a water inrush through KCCs:

- $\quad$ Presence of a karst aquifer that can supply a sustainable water source;

- $\quad$ Active KCCs that are permeable to water; and

- Significantly higher water pressure in the karst aquifer than the elevation of the underground working area, providing the necessary force for water flow.

Therefore, proactive detection of any concealed KCCs and determination of their hydrogeological characteristics have become essential components of a comprehensive investigation program in preventing water inrush incidents and ensuring normal coal production in the mine.

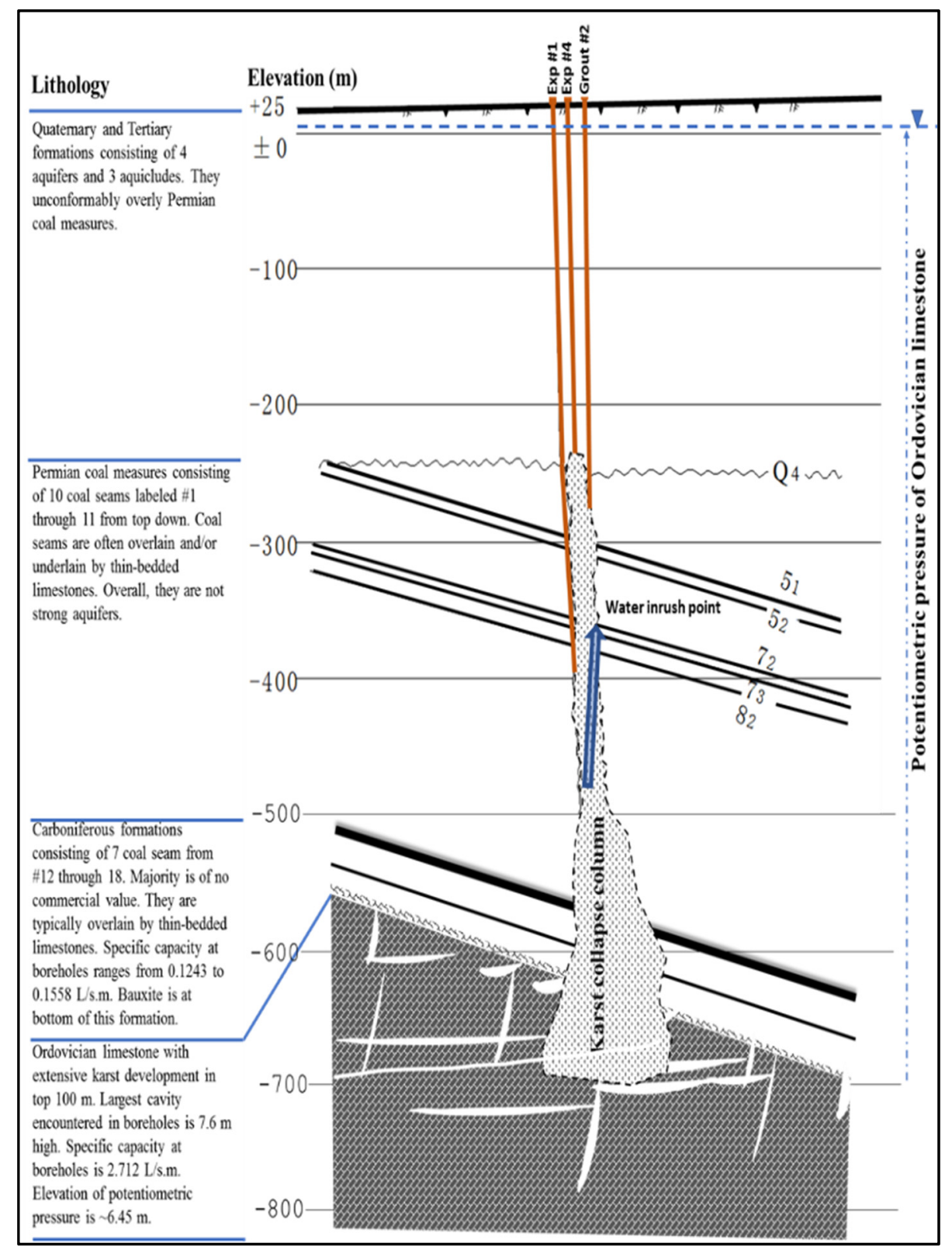

Figure 5. Schematic depicting lithology and 1996 water Inrush at Renlou Coal Mine, China 


\section{Detection and Remediation of a Concealed Karst Collapse Column in Renlou Coal Mine}

In June 2010, an anchor hole advanced in II $5_{1}$ Tunnel encountered groundwater. The tunnel was at elevations from -718.6 to $-720.1 \mathrm{~m}$ bsl and was excavated for mining $\# 5_{1}$ coal seam. The tunnel was $440 \mathrm{~m}$ below the Quaternary and Tertiary formations and at least $300 \mathrm{~m}$ above the Ordovician limestone. The stratigraphy encountered by the tunnel consisted of fine sandstone and mudstone with petrified plant parts. Under normal conditions, water in these formations was limited and did not pose safety threat to underground workings. The tunnel also intercepted a normal fault, $\mathrm{DF}_{8}$, with $5 \mathrm{~m}$ displacement. No water seepage was observed through the fault.

\subsection{Water Source Discrimination by Temperature and Hardness Measurements}

As shown in Figure 6, two exploration boreholes, 4-3 and 4-3', were advanced at different angles to investigate the source and pathway of the groundwater encountered at the anchor hole. At an angle of $47^{\circ}$, borehole 4-3 intercepted fault $\mathrm{DF}_{8}$, whereas at an angle of $40^{\circ}$, borehole 4-3' intercepted a high-angled $\left(75^{\circ}\right)$ fracture. The maximum groundwater flow rate at borehole $4-3$ was $2 \mathrm{~m}^{3} / \mathrm{h}$, and the maximum flow rate at borehole $4-3$ ' was $16 \mathrm{~m}^{3} / \mathrm{h}$.

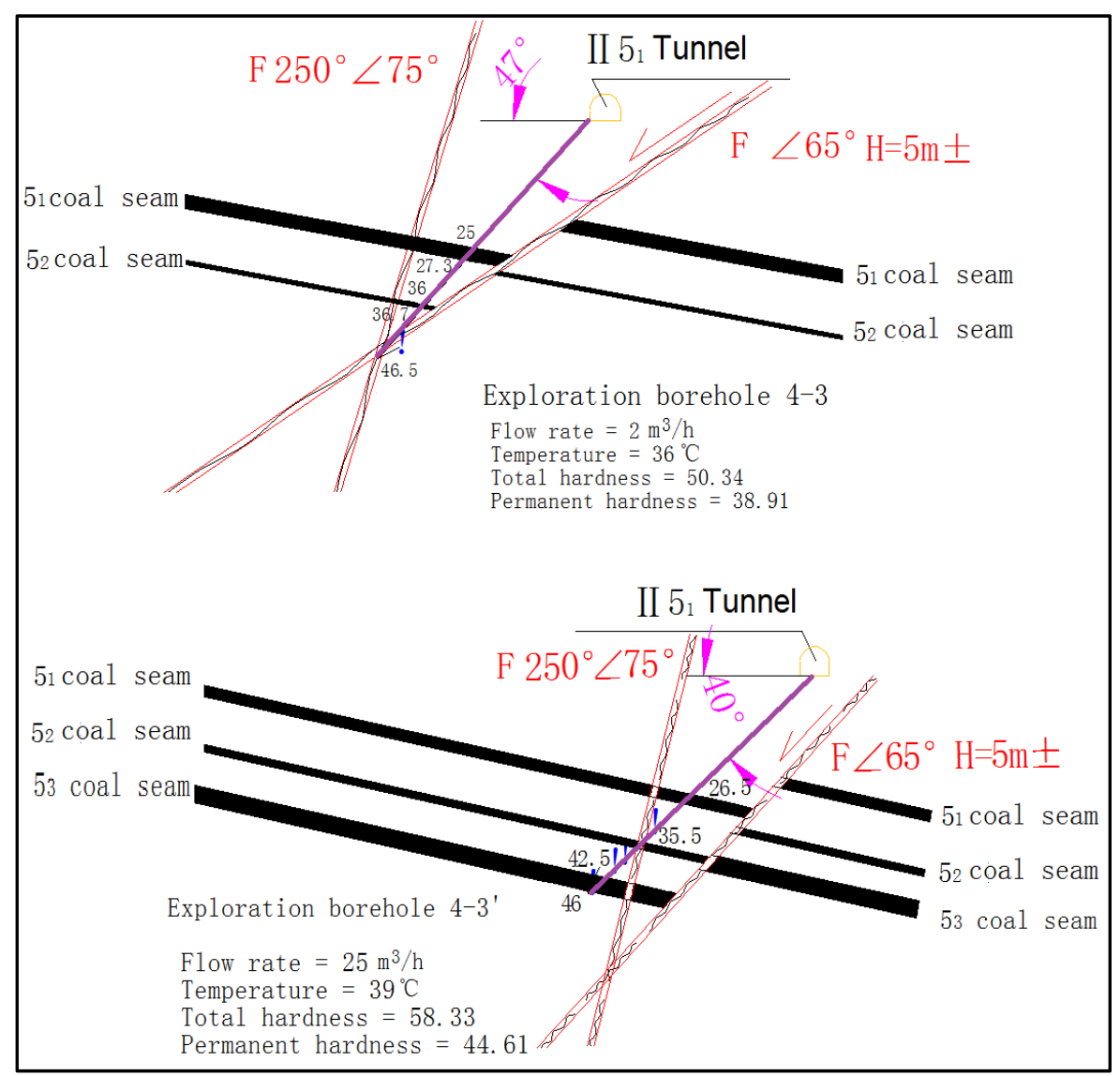

Figure 6. Layout of boreholes 4-3 and 4-3' for exploration of water sources

Figure 7 shows changes of water temperature and hardness at borehole 4-3 from June 2010 to November 2011. Data at borehole 4-3' had similar trends. Over a period of 17 months, the water temperature gradually increased from 33 to $41^{\circ} \mathrm{C}$. The normal earth temperature at this elevation in the mine is approximately $35^{\circ} \mathrm{C}$. The higher than normal temperature in the inflow water indicated that the water source was from deeper formations.

Two types of hardness are presented in Figure 7, the total hardness was measured prior to boiling and permanent hardness was measured after boiling. Their unit is degree of General Hardness or German degree (dGH). Both types of hardness show a general trend of increasing. The total hardness increased from 8.34 to $60.58 \mathrm{dGH}$, whereas the permanent hardness increased from 0 to $48.81 \mathrm{dGH}$. The persistent increases in the hardness also suggest that the water sources were from the deeper formations. The measured temperature and hardness at end of the monitoring period were similar to those measured in the Ordovician limestone in the mine. 


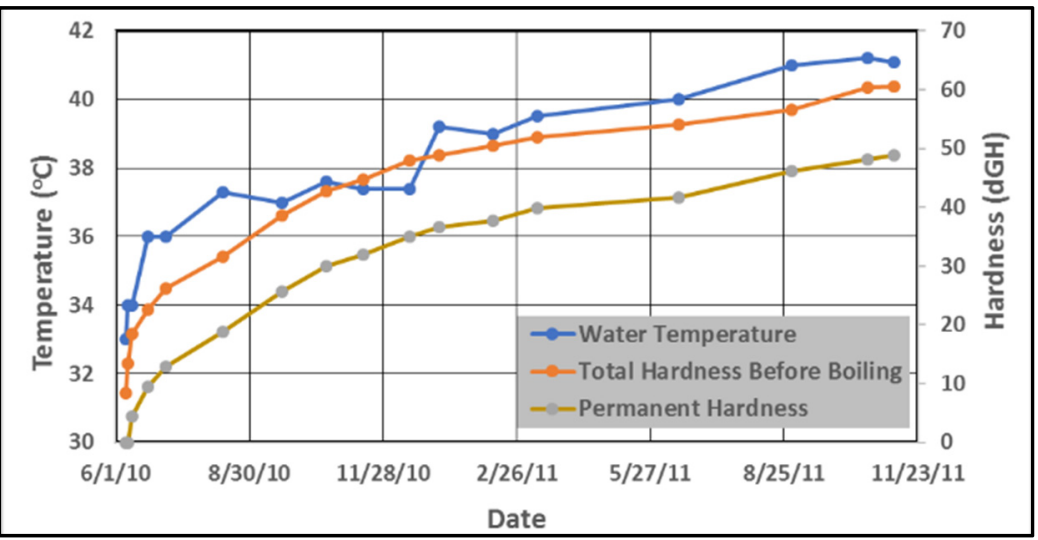

Figure 7. Water temperature and hardness measurements at boreholes 4-3

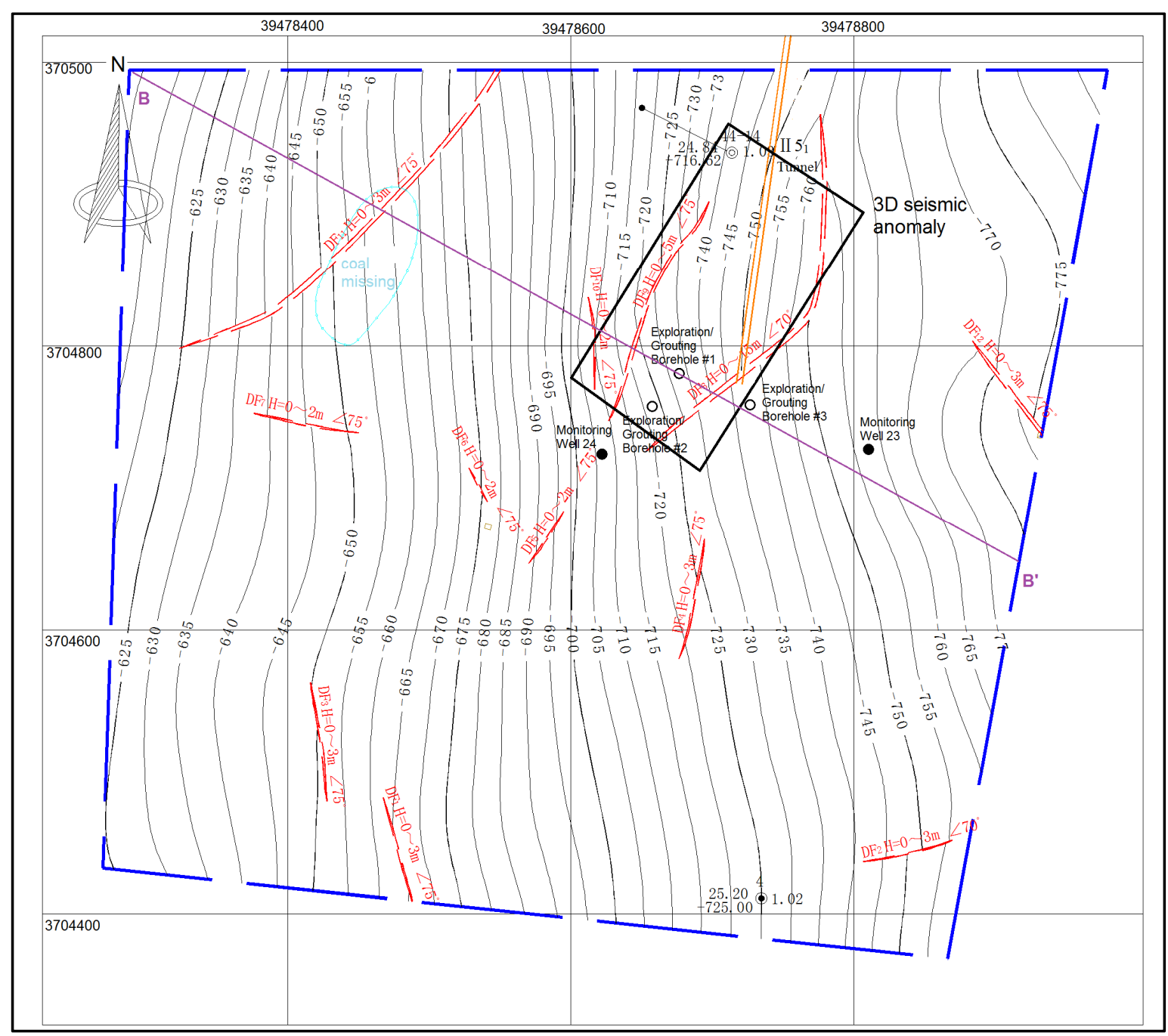

Figure 8 . Contours of 5 coal seam elevation as interpreted from 3D seismic survey

\subsection{Geophysical Investigations}

Geophysical surveys were conducted to investigate any geologically and hydrogeologically anomalous areas. Time domain electromagnetic methods (TDEM) and 3D seismic were used on the ground surface, while TDEM, 3D seismic, earth resistivity imaging, and ground penetrating radar were used underground in II 51 Tunnel. 
Anomalies identified and verified from multiple geophysical techniques were considered the targets for further investigations. Figure 8 shows an example of 3D seismic interpretation of the $\# 5_{1}$ coal seam elevation. The rectangular is a geophysical anomaly in which the coal seam elevations were distorted. A vertical profile of the 3D seismic is shown in Figure 9. The geophysical anomaly was interpreted to be associated with a KCC.

\subsection{Borehole Exploration}

Figure 8 shows the locations of three exploratory and grouting boreholes \#1, \#2, and \#3, and two monitoring wells \#23 and \#24. The monitoring wells were installed to monitor potentiometric pressures of the Ordovician limestone. The exploratory boreholes were drilled in the order of \#1, \#2, and \#3. They were drilled in the geophysically interpreted anomaly to investigate the subsurface conditions, in particular, to confirm presence of the KCC. If the KCC was confirmed, these boreholes were then used as grouting holes to construct a water plug within the collapse feature. Borehole \#1 was vertical, while directional drilling was used in both boreholes \#2 and \#3 to intercept the KCC encountered in borehole \#1. Figures 10 and 11 shows the profiles from borehole \#1 through borehole \#2 to monitoring well 24 and from borehole \#1 through borehole \#3 to monitoring well 23, respectively. Table 3 summarizes the pertinent observations in these three boreholes.

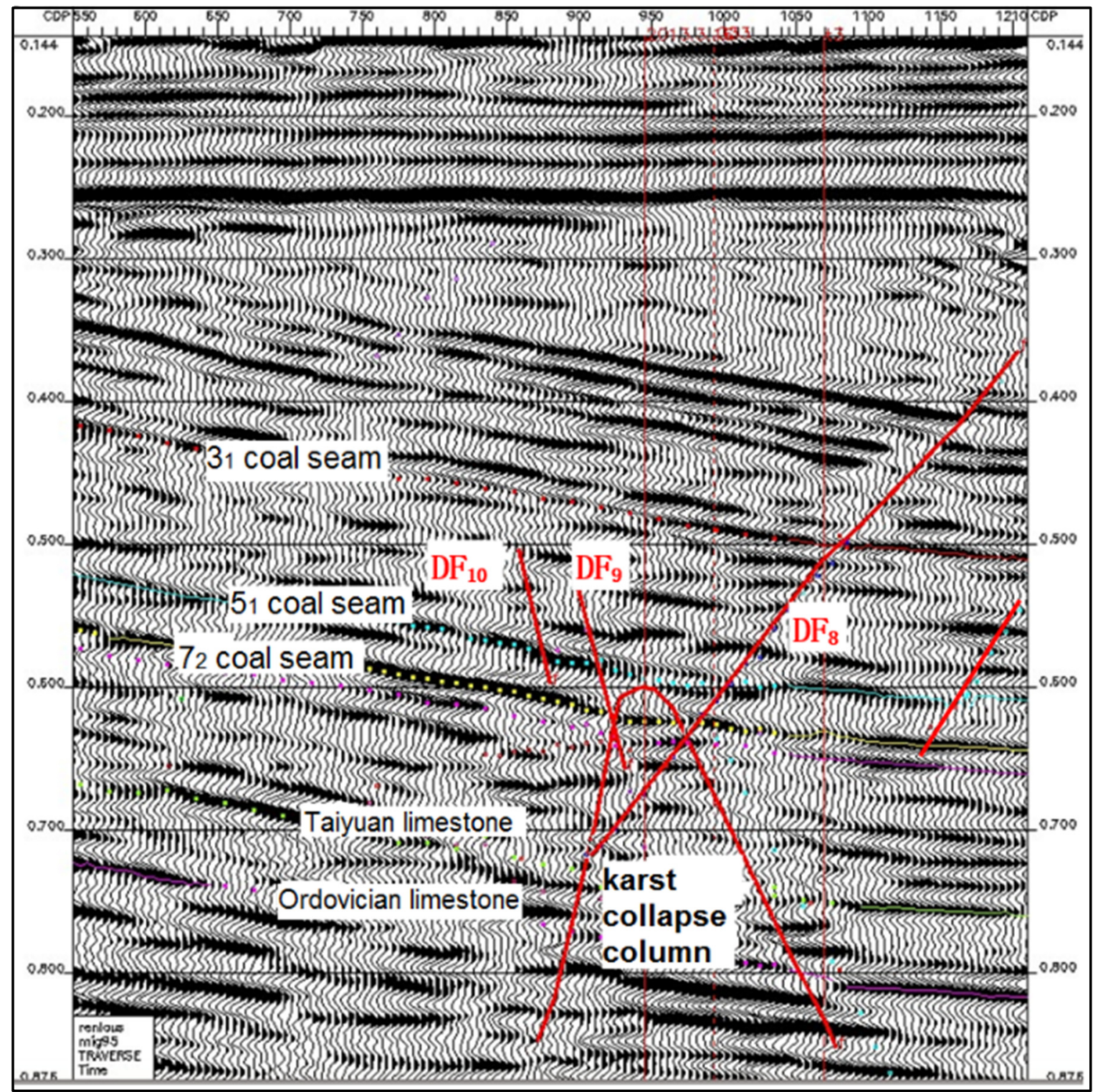

Figure 9. A cross-section of 3D seismic survey (location of the cross-section is shown in Figure 8) 


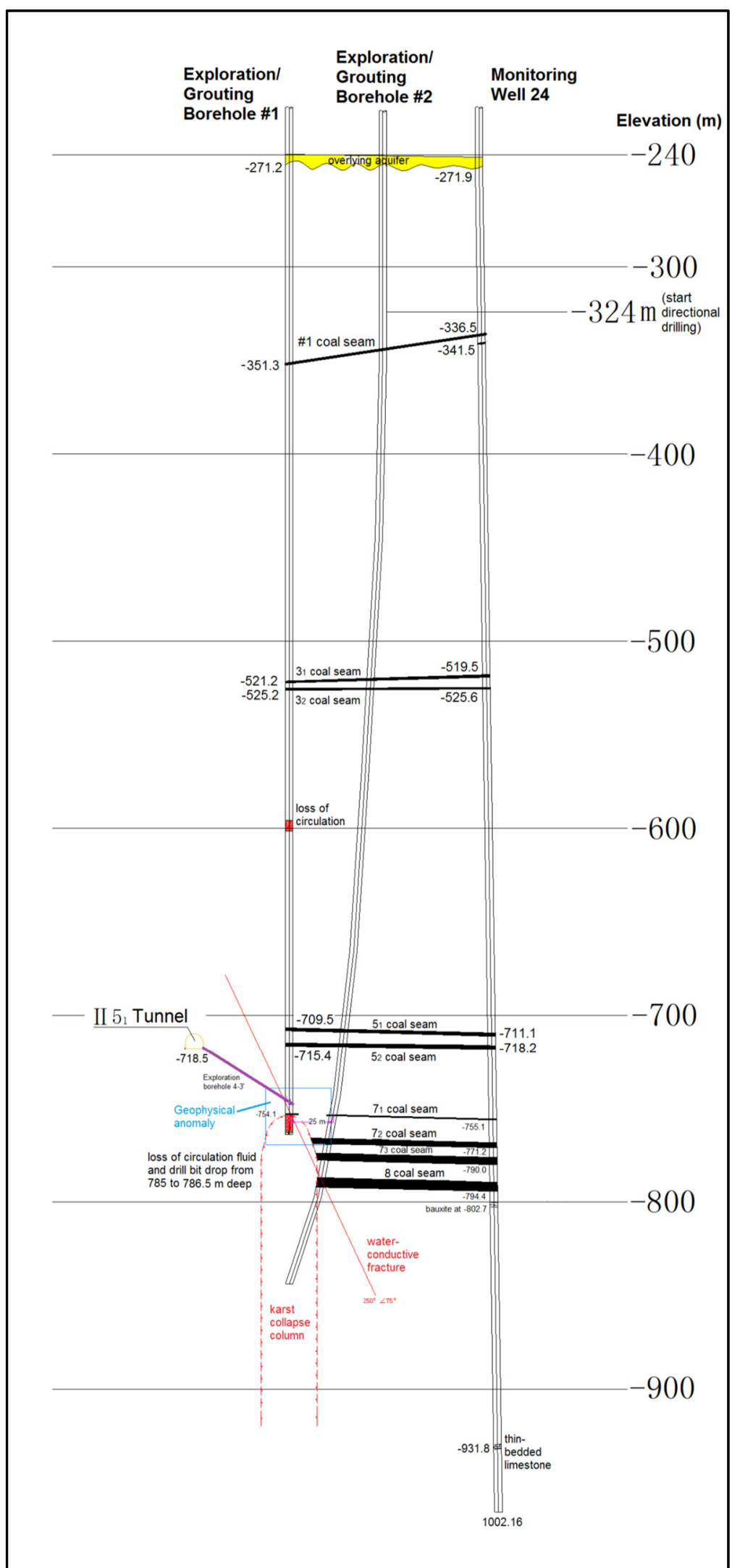

Figure 10. Profile of exploration/grouting boreholes \#1 and \#2 


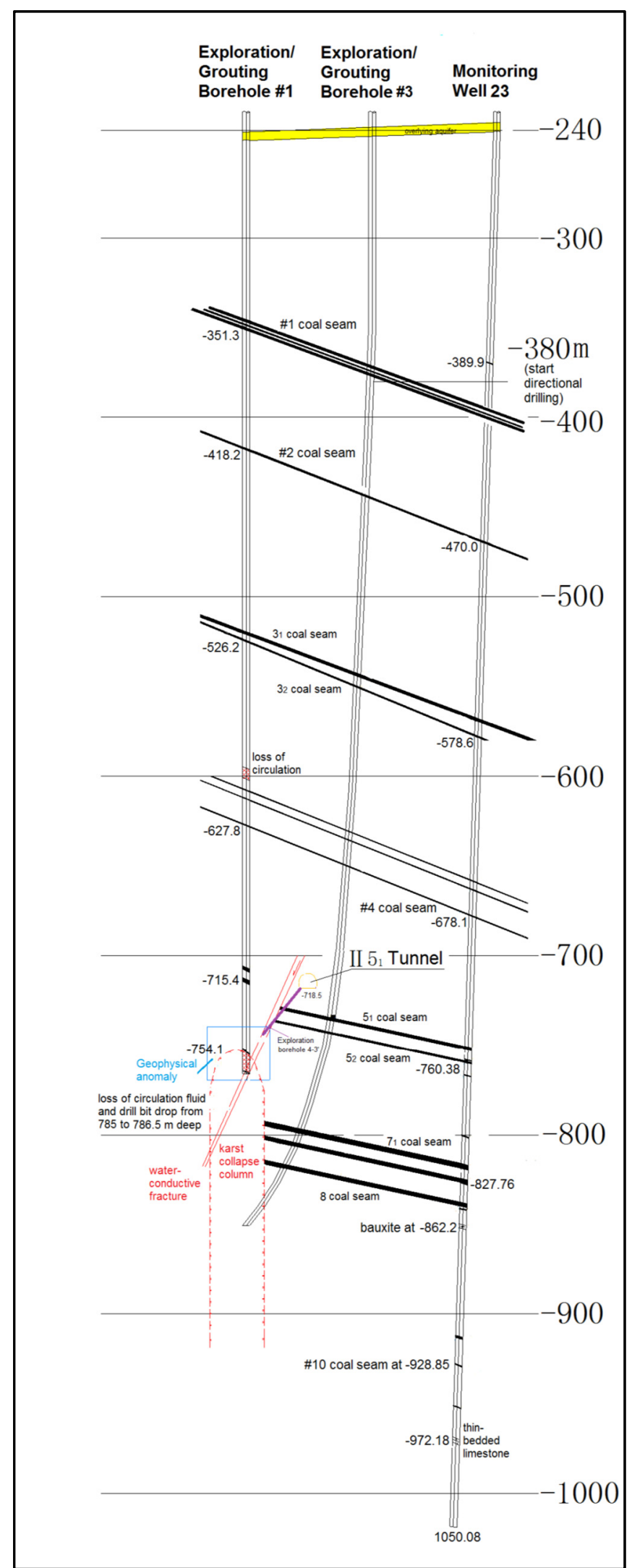

Figure 11. Profile of exploration/grouting boreholes \#1 and \#3 
Table 3. Summary of drilling parameters at three exploration/grouting boreholes

\begin{tabular}{|c|c|c|c|}
\hline \multirow{2}{*}{ Parameters } & \multicolumn{3}{|c|}{ Exploration/Grouting Boreholes } \\
\hline & $\# 1$ & $\# 2$ & $\# 3$ \\
\hline Total depth (m) & 920.48 & 920.57 & 986 \\
\hline Directional drilling & & At $350 \mathrm{~m}$ toward borehole \#1 & $\begin{array}{l}\text { At } 380 \mathrm{~m} \text { toward } \\
\text { borehole } \# 1\end{array}$ \\
\hline Depth to bedrock (m) & 271.2 & 273.7 & 273.1 \\
\hline Depth to \#1 coal seam (m) & 376.8 & $360.0-369.6$ & 395.05 \\
\hline Depth to \#5 coal seam (m) & 740.8 & 764.9 & 758.7 \\
\hline Loss of circulation intervals (m) & $\begin{array}{l}\text { - } \quad 627-694 \\
\text { - } \quad 785-787\end{array}$ & $\begin{array}{ll}\text { - } & 609-619 \\
\text { - } & 773-775 \\
\text { - } & 863 \text { to } 865 \\
\text { - } & 885\end{array}$ & $\begin{array}{ll}\text { - } & 739 \\
983 & \end{array}$ \\
\hline Drilling bit drop (m) & $\begin{array}{l}1.5 \mathrm{~m} \text { from } 785 \text { to } 786.5 \text {; likely } \\
\text { entering collapse body }\end{array}$ & $\begin{array}{l}2 \mathrm{~m} \text { from } 773 \text { to } 775 \text {; likely entering } \\
\text { collapse body }\end{array}$ & \\
\hline Grouting (t) & $\begin{array}{l}1,366 \mathrm{t}(935 \mathrm{tons} \text { at } 791 \mathrm{~m} ; 81 \mathrm{t} \\
\text { at } 820 \mathrm{~m} ; 159 \mathrm{t} \text { at } 842 \mathrm{~m} ; 191 \mathrm{t} \text { at } \\
900 \mathrm{~m})\end{array}$ & $\begin{array}{l}1,920 \mathrm{t}(445 \mathrm{t} \text { at } 803 \mathrm{~m} ; 245 \mathrm{t} \text { at } 835 \mathrm{~m} \text {; } \\
180 \mathrm{t} \text { at } 855 \mathrm{~m} ; 110 \mathrm{t} \text { at } 865 \mathrm{~m} ; 270 \mathrm{t} \text { at } \\
865.5 \mathrm{~m} ; 140 \mathrm{t} \text { at } 885 \mathrm{~m} ; 70 \mathrm{t} \text { at } 905 \mathrm{~m} \text {; } \\
420 \mathrm{t} \text { at } 920.57)\end{array}$ & $295 \mathrm{t}$ at $911 \mathrm{~m}$ \\
\hline $\begin{array}{l}\text { Post-grouting water intake } \\
\text { capacity (L/min.m.m) }\end{array}$ & 0.00099 & 0.00091 & 0.00214 \\
\hline
\end{tabular}

Both boreholes \#1 and \#2 encountered drill bit drops and total loss of circulation. The bit drops at boreholes \#1 and \#2 were $1.5 \mathrm{~m}$ and $2 \mathrm{~m}$, respectively. The loss of circulation was greater than $72 \mathrm{~m}^{3} / \mathrm{h}$ where the drill bit drops occurred. The drops occurred at depths between 773 and $787 \mathrm{~m}$. Such characteristics were atypical of the formations at these intervals unless a KCC or large fracture was present. The exploratory and geophysical results suggested that this feature was likely a KCC. The KCC had an oval shape, and its dimensions were estimated to be $55 \mathrm{~m}$ in the long axis and $40 \mathrm{~m}$ in the short axis. The bottom of the KCC was unknown and its roof was approximately $20 \mathrm{~m}$ below $\# 5$ coal seam.

Grouting at boreholes \#1 and \#2 further confirmed that both boreholes intercepted the top of the KCC. Grouting materials injected at borehole \#1 were observed at borehole \#2 as well as in II 51 Tunnel. Since borehole \#3 was advanced after grouting at boreholes \#1 and \#2 was completed, it encountered cement-filled void and the amount of grout was significantly reduced in borehole \#3. Water injection tests were conducted at all three boreholes before completing the grouting. The results (Table 3 ) demonstrated that the water intake capacity was less than the designed value of $0.01 \mathrm{~L} / \mathrm{min} . \mathrm{m} . \mathrm{m}$. The water intake capacity was calculated by water injection rate $(\mathrm{L} / \mathrm{min})$ divided by applied pressure ( $\mathrm{m}$ of water) and test interval $(\mathrm{m})$. Another indicator of the grouting success was that the post-grouting groundwater flow into II $5_{1}$ Tunnel was minimal and the remaining water seeped from the overlying formations as verified with water quality parameters. The water levels in monitoring wells 23 and 24 were measured to ensure the long-term success of the investigation and remediation effort.

\section{Conclusions}

KCCs are karst features that were often encountered in mines of north China. Because these karst features could be several hundred meters high, they can connect multiple aquifers and lead water to underground workings under the following conditions:

- The KCC is active and permeable to water.

- The KCC is connected to water-bearing media (aquifers or water pools) that can supply a significant water source.

- The water pressure in the water-bearing media is higher than the elevation of the underground working area.

Because of potential damages that can be caused by these structures in mines, proactive detection of any concealed KCCs and determination of their hydrogeological characteristics are essential components of mine water control and prevention programs in China. Multiple techniques including geochemistry, geophysics, directional drilling, grouting, and water injection testing were proved to be effective in detecting and characterizing a concealed KCC in Renlou Coal Mine. The risks posted by the KCC were successfully mitigated by directional grouting. 


\section{References}

Andrajchouk, V., \& Klimchouk, A. (1993). Environmental change and human Impact on karst in the Western Ukraine. Catena Supplement, 25, 147-147.

Beck, B. F. (1984). Sinkholes: their geology, engineering and environmental impact. Proceedings of the First Multidisciplinary Conferente on Smkholes/Orlando/Florida, 117.

Beck, B. F. (1991). On calculating the risk of sinkhole collapse. In E. H. Kasning (Ed.), Appalachian karst. Nat. Speleological Soc. (pp. 231-236). Huntsville, AL.

Beck, B. F., Multidisciplinary Conference on Sinkholes, \& the Environmental Impacts of Karst (2: 1987: Orlando). (1987). Karst hydrogeology: engineering and environmental applications: proceedings of the Second Multidisciplinary Conference on Sinkholes and the Environmental Impacts of Karst, Orlando, Florida, 9-11 February 1987. AA Balkema.

Benson, R. C., Yuhr, L., \& Hatheway, A. L. (1991, November). Ground water monitoring in unsaturated and saturated zones at a site with paleocollapse structures. In annual meeting and 10th anniversary of the American Institute of Hydrology International conference on hydrology and hydrogeology (pp. 3-7).

Dong, S. N. (2016). Study on the optimal allocation of water resources systems and the comprehensive utilization of water resources in arid-semiarid multiple mining areas. Springer.

Li, G., \& Zhou, W. (2006). Impact of karst water on coal mining in North China. Environmental Geology, 49(3), 449-457. https://doi.org/10.1007/s00254-005-0102-3

Li, G., \& Zhou, W. (2015). Karst paleo-collapses and their impacts on mining and the environment in northern China (pp. 147-156). NCKRI symposium 5, Proceedings of 14th Sinkhole Conference.

Li, H., Bai, H., Wu, J., Zhao, H., \& Ma, K. (2017). A method for prevent water inrush from karst collapse column: a case study from Sima mine, China. Environmental Earth Sciences, 76(14), 493. https://doi.org/10.1007/s12665-017-6831-2

Li, J. K., \& Zhou, W. F. (1989). Geohydrogeological environment for and prediction of water outburst through collapse-columns in coalfields of north China. Carsologica Sinica, 8, 192-199.

Li, J. K., \& Zhou, W. F. (1990). Studies on the control and management of karst water from Ordovician limestone in Collieries, North China. Xian: Shaanxi People's Publishing House.

Lu, Y. R., \& Cooper, A. H. (1997). Gypsum karst geohazards in China. In F. B. Beck, \& J. B. Stephenson (Ed.), The Engineering Geology and Hydrogeology of Karst Terranes. Proceedings of the Sixth Multidisciplinary Conference on Sinkholes and the Engineering and Environmental Impacts of Karst Springfield/Missouri/6-9 April 1997. A.A. Balkema, Rotterdam.

Lu, Y. R., \& Zheng, F. (2008). Research on development mechanism of sulphate-carbonate rocks' compound karst and engineering impacts. Engineering Sciences of China, 10(4), 4-10.

Newton, J. G. (1987). Development of sinkholes resulting from man's activities in the eastern United States. US Geological Survey Circular 968.

Sangster, D. F. (1988). Breccia-hosted lead-zinc deposits in carbonate rocks. In N. P. James, \& P. W. Choquette (Eds.), Paleokarst (pp. 102-116). New York: Springer.

Vegter, J. R., \& Foster, M. B. J. (1992). The hydrogeology of dolomitic formations in the southern and western Transvaal. Hydrogeology of Selected Karst Regions.-International Contributions to Hydrogeology, 13, 355-376.

Waltham, A. C. (1989). Ground subsidence. London: Blackie \& Son.

Wanfang, L. J. Z. (1989). GEOHYDROLOGICAL ENVIRONMENT FOR AND PREDICTION OF WATER OUTBURST THROUGH COLLAPSE-COLUMNS IN COALFIELDS OF NORTH CHINA [J]. Carsologica Sinica, 3, 001.

White, W. B. (1988). Geomorphology and hydrology of karst terrains. Oxford: Oxford University Press.

Wigley, T. L. M. (1973). Chemical evolution of the system Calcite-Gypsum-Water. Canadian Journal of Earth Sciences, 10, 306-315. https://doi.org/10.1139/e73-027 
Wu, Q., Fan, S., Zhou, W., \& Liu, S. (2013). Application of the analytic hierarchy process to assessment of water inrush: a case study for the no. 17 coal seam in the Sanhejian Coal Mine, China. Mine Water Environ, 32 , 229-238. https://doi.org/10.1007/s10230-013-0228-6

Yin, S. X., \& Zhang, J. C. (2005). Impacts of karst paleo-sinkholes on mining and environment in Northern China. Environ Geol, 48, 1077-1083. https://doi.org/10.1007/s00254-005-0046-7

Yuan, D. X. (1987). Environmental and engineering problems of karst geology in China. In B. F. Beck, \& W. L. Wilson (Eds.), Karst hydrogeology: engineering and environmental applications (pp. 1-11). A.A. Balkema, Rotterdam.

Zhou, W. F. (1997). Paleocollapse structure as a passageway for groundwater flow and contaminant transport. Environmental Geology, 32(4), 251-257. https://doi.org/10.1007/s002540050214

Zhou, W., Beck, B. F. (2011). Engineering Issues on Karst. In P. E. van Beynen (Ed.), Karst Management. New York: Springer.

Zou, C. J. (1994). Hydraulic and hydroelectric karst engineering geology. Beijing: Hydraulic and Hydroelectric Publishing House.

\section{Copyrights}

Copyright for this article is retained by the author(s), with first publication rights granted to the journal.

This is an open-access article distributed under the terms and conditions of the Creative Commons Attribution license (http://creativecommons.org/licenses/by/4.0/). 